\title{
The impact of economic crises on social inequalities in health: what do we know so far?
}

\author{
Amaia Bacigalupe $^{1 *}$ and Antonio Escolar-Pujolar ${ }^{2}$
}

\begin{abstract}
Since 2008, Western countries are going through a deep economic crisis whose health impacts seem to be fundamentally counter-cyclical: when economic conditions worsen, so does health, and mortality tends to rise. While a growing number of studies have presented evidence on the effect of crises on the average population health, a largely neglected aspect of research is the impact of crises and the related political responses on social inequalities in health, even if the negative consequences of the crises are primarily borne by the most disadvantaged populations. This commentary will reflect on the results of the studies that have analyzed the effect of economic crises on social inequalities in health up to 2013. With some exceptions, the studies show an increase in health inequalities during crises, especially during the Southeast Asian and Japanese crises and the Soviet Union crisis, although it is not always evident for both sexes or all health or socioeconomic variables. In the Nordic countries during the nineties, a clear worsening of health equity did not occur. Results about the impacts of the current economic recession on health equity are still inconsistent. Some of the factors that could explain this variability in results are the role of welfare state policies, the diversity of time periods used in the analyses, the heterogeneity of socioeconomic and health variables considered, the changes in the socioeconomic profile of the groups under comparison in times of crises, and the type of measures used to analyze the magnitude of social inequalities in health. Social epidemiology should further collaborate with other disciplines to help produce more accurate and useful evidence about the relationship between crises and health equity.
\end{abstract}

Keywords: Economic crisis, Health inequalities

\section{Introduction}

Since 2008, Western countries are going through a deep crisis which has deeply penetrated into the economic, social, political and even ethical spheres of our societies. The high rates of unemployment, and increased poverty and social inequalities, particularly in southern Europe, are among its worst effects [1]. The neoliberal economic policies developed by most countries and imposed by the International Monetary Fund, the European Central Bank and the European Commission are hindering the process of decommodification -accessibility to public goods and services not provided by the market- that defined the model of welfare state in Europe during the last decades.

Evidence shows that the relationship between economic crises and health is fundamentally counter-cyclical:

\footnotetext{
* Correspondence: amaia.bacigalupe@ehu.es

${ }^{1}$ Department of Sociology 2, University of the Basque Country (UPV/EHU), Leioa, Spain

Full list of author information is available at the end of the article
}

when economic conditions worsen, so do physical and mental health, and mortality tends to rise [2]. However, a pro-cyclical relationship has also been described, so that mortality increases in periods of expansion and decreases during economic downturns [3]. This could be due to improving health of people who remain in the labour market during recessions and the decline of some causes of death, which would compensate for the deterioration of health in other groups [4].

One aspect that has scarcely been researched so far is the impact of the economic crises on social inequalities in health [5]. At present it is clear that the negative consequences of the crisis are being primarily borne by the most disadvantaged populations, who are concentrating the major risks of some crucial social determinants of health, such as unemployment and poverty [6]. Moreover, the austerity policies are leaving these populations especially vulnerable to such disadvantages [7].

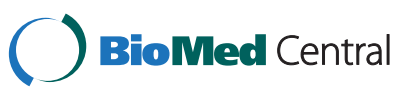


Many studies in recent years have shown that the unequal distribution of the social determinants of health undermines health equity [8]. However, the change in the pattern of social inequalities does not directly affect the profile of social inequalities in health within a population, since the interactions between both phenomena are complex $[9,10]$. The objective of this commentary is to reflect on the results of the peer-reviewed articles that have specifically analyzed the effect of economic crises on social inequalities in population health up to 2013. From their conclusions, we propose some ideas for a better understanding of what the effects of the current crisis and the austerity policies on health equity might be. Only studies that considered a pre-crisis period in their analyses and used some measure of socioeconomic position were included. On the contrary, the publications that did not clearly define which crisis they were referring to -since changes derived from more general economic restructuration processes or from economic stagnations were evaluated- were not included. The search was done in Pubmed and complemented with the revision of the references included in the retrieved articles.

\section{What are the consequences of crises on health inequalities?}

The studies examined the effect of various economic crises during the nineties of the last century -the Soviet crisis, the financial crisis in Southeast Asia and Japan, and the crisis in the Nordic countries- as well as of the Great Recession beginning in 2008 (Table 1). They used diverse outcome variables -overall mortality, causes of death, and physical and mental health- and socioeconomic variables -mainly educational level, social class and employment status-. The periods analyzed were also heterogeneous, ranging from $4[11,12]$ to 45 years [13]. Despite the existing evidence on the uneven effects of crises upon men and women [7], many studies did not stratify results by sex $[11,12,14-17]$.

With some exceptions [12,18-23], an increase in health inequalities during crisis periods is observed, although it is not always evident for both sexes [24-26] or for all health or socioeconomic variables [11,14,15,25-27]. The increase of inequalities in mortality was clear in Russia during the Soviet crisis $[16,28]$, and in Korea and Japan during the Asian crises $[13,29,30]$. In Korea inequalities went up in mental health and self-perceived health $[17,26,31]$, while less consistent results were observed in other studies of Japan $[23,25]$. Regarding the Great Recession, UK studies do not show an increase in health inequalities [12,32], with the exception of excessive alcohol consumption [14]. In Spain increased inequalities are observed in diagnosed mental pathology [11], healthrelated quality of life in children [15], perinatal health outcomes [27], and men's mental health [24].
A clear exception occurred in the Nordic countries during the nineties, in which an increase in health inequalities was not observed. Indeed, inequalities in longstanding illness and self-perceived health decreased $[18,19]$, and mortality did not increase more than it was already doing before the crisis in Finland [20]. Additionally, other studies show that inequalities in cardiovascular mortality, disability and self-perceived health in Sweden and Finland remained stable during the crisis $[21,22]$.

\section{Why are these results observed? Reflections on the effect of the crises on health inequalities}

According to the evidence on the impact of social determinants on health equity [8], increasing social inequality and poverty, greater job insecurity, rising unemployment, and privatization of public goods and services [7] can explain the increase in social inequalities in health during crises, as mainly described by the studies in Table 1 .

However, some results also show that economic recessions are not always accompanied by an increase in social inequalities in health. Indeed, it seems that the role of welfare state policies during periods of recession is key to buffer the growth of inequalities, as happened in the Nordic countries during the crisis of the nineties [18]. Although there is no clear evidence that social inequalities in health are generally lower in the Nordic countries [33], it appears that their safety nets were effective in preventing the growth of social inequalities in health when economic conditions deteriorated. This probably prevented the most vulnerable groups from losing access to public goods and services, further social exclusion, and a decrease in their political advocacy capacity [9].

Additionally, there must be other factors explaining why in other countries where living conditions have deteriorated and austerity policies have been implemented in times of crisis, inequalities have not clearly risen [11,12,14,15,23-27]. Without being exhaustive, the following factors could partially explain this phenomenon:

Firstly, the diversity of time periods used may provide interesting clues: the use of short periods for the analyses-which is especially evident in the studies about the current crisis- makes it difficult to capture the long term effects on health inequalities. Indeed, it has been reported that the impact of unemployment and other adverse circumstances on health in times of crisis can be evident only after many years, especially in disadvantaged populations [34]. It is also very important to have a sufficient time-perspective prior to the beginning of the crisis in order to assess whether the crisis itself has had an added effect on trends that were already occurring. This perspective is usually absent in the studies analyzing the effects of the current economic crisis $[11,12,15,24]$. 
Table 1 Studies about the effect of economic crises on social inequalities in health

\begin{tabular}{|c|c|c|c|c|c|c|c|}
\hline Crisis & Country & Study period & Reference & Main health variable & $\begin{array}{l}\text { Main socioeconomic } \\
\text { variable }\end{array}$ & $\begin{array}{l}\text { Analyses } \\
\text { by sex }\end{array}$ & Main results \\
\hline \multirow{7}{*}{ Great recession } & United Kingdom & 2006-2010 & Astell-Burt \& Feng [12] & Limiting long-standing illness & Working status & No & $\begin{array}{l}\text { Inequalities in limiting long-standing } \\
\text { illness decreased from } 2008\end{array}$ \\
\hline & United Kingdom & 2004-2010 & Harhay et al. [14] & Binge drinking & Working status; Income & No & $\begin{array}{l}\text { The beginning of the crisis entailed } \\
\text { an elevated risk of binge drinking } \\
\text { among the unemployed. Income- } \\
\text { related inequalities did not increase }\end{array}$ \\
\hline & United Kingdom & $1991-2010$ & Katikireddi et al. [32] & Mental health (GHQ-12) & $\begin{array}{l}\text { Educational level; } \\
\text { deprivation level }\end{array}$ & Yes & $\begin{array}{l}\text { Inequalities in mental health were } \\
\text { already increasing before } 2008\end{array}$ \\
\hline & Spain & 2006-2012 & Rajmil et al. [15] & $\begin{array}{l}\text { Obesity; Health behaviours; } \\
\text { Mental health; Heath-related } \\
\text { quality of life }\end{array}$ & $\begin{array}{l}\text { Mothers' educational level; } \\
\text { Family's working status }\end{array}$ & No & $\begin{array}{l}\text { Inequalities in obesity among } \\
\text { children did not change while } \\
\text { inequalities in health-related quality } \\
\text { of life increased }\end{array}$ \\
\hline & Spain & 2006-2010 & Gili et al. [11] & Mental health & $\begin{array}{l}\text { Educational level; Working } \\
\text { status }\end{array}$ & No & $\begin{array}{l}\text { Excepting the decrease of working } \\
\text { status related inequalities in } \\
\text { dysthymia, inequalities increased in } \\
\text { all other mental health indicators }\end{array}$ \\
\hline & Spain & 2001-2011 & Juárez et al. [27] & Perinatal health & Mothers' educational level & Only women & $\begin{array}{l}\text { Inequalities increased in macrosomia } \\
\text { and in post-term births and did not } \\
\text { increase in low birthweight and } \\
\text { pre-term births }\end{array}$ \\
\hline & Spain & 2006-2012 & Bartoll et al. [24] & Mental health (GHQ-12) & Social class; Educational level & Yes & Inequalities increased only in men \\
\hline \multirow{5}{*}{ Nordic crisis } & Finland & 1981-1995 & Valkonen et al. [20] & $\begin{array}{l}\text { Total and cause-specific } \\
\text { mortality }\end{array}$ & Social class & Yes & $\begin{array}{l}\text { Inequalities were already increasing } \\
\text { before the crisis, and continued } \\
\text { growing afterwards }\end{array}$ \\
\hline & Finland & 1986-1994 & Lahelma et al. [18] & $\begin{array}{l}\text { Limiting long-standing illness; } \\
\text { Self-perceived health }\end{array}$ & $\begin{array}{l}\text { Educational level; Working } \\
\text { status }\end{array}$ & Yes & $\begin{array}{l}\text { Inequalities decreased in men } \\
\text { (especially regarding limiting long- } \\
\text { standing illness), and remained stable } \\
\text { in women }\end{array}$ \\
\hline & Finland & 1993-2002 & Lammintausta et al. [21] & $\begin{array}{l}\text { Incidence and mortality for } \\
\text { coronary disease }\end{array}$ & Income & Yes & $\begin{array}{l}\text { Inequalities did not change during } \\
\text { the period }\end{array}$ \\
\hline & Sweden & 1986-1995 & Lundberg et al. [22] & $\begin{array}{l}\text { Self-perceived health; Limiting } \\
\text { long-standing illness }\end{array}$ & $\begin{array}{l}\text { Social class; Educational } \\
\text { level; Working status }\end{array}$ & Yes & $\begin{array}{l}\text { Inequalities did not change during } \\
\text { the period }\end{array}$ \\
\hline & Nordic countries & 1986-1995 & Lahelma et al. [19] & $\begin{array}{l}\text { Self-perceived health; Limiting } \\
\text { long-standing illness }\end{array}$ & $\begin{array}{l}\text { Working status; Educational } \\
\text { level }\end{array}$ & Yes & $\begin{array}{l}\text { Inequalities slightly decreased in men } \\
\text { and did not change in women }\end{array}$ \\
\hline \multirow[t]{2}{*}{ Soviet Union crisis } & Russia & 1980-2001 & Murphy et al. [28] & Life expectancy and mortality & Educational level & Yes & $\begin{array}{l}\text { Inequalities in life expectancy } \\
\text { increased especially among men } \\
\text { since } 1990\end{array}$ \\
\hline & Russia & 1975-1998 & Plavinski et al. [16] & $\begin{array}{l}\text { Total and cause-specific } \\
\text { mortality }\end{array}$ & Educational level & No & Inequalities increased during the $90 \mathrm{~s}$ \\
\hline
\end{tabular}


Table 1 Studies about the effect of economic crises on social inequalities in health (Continued)

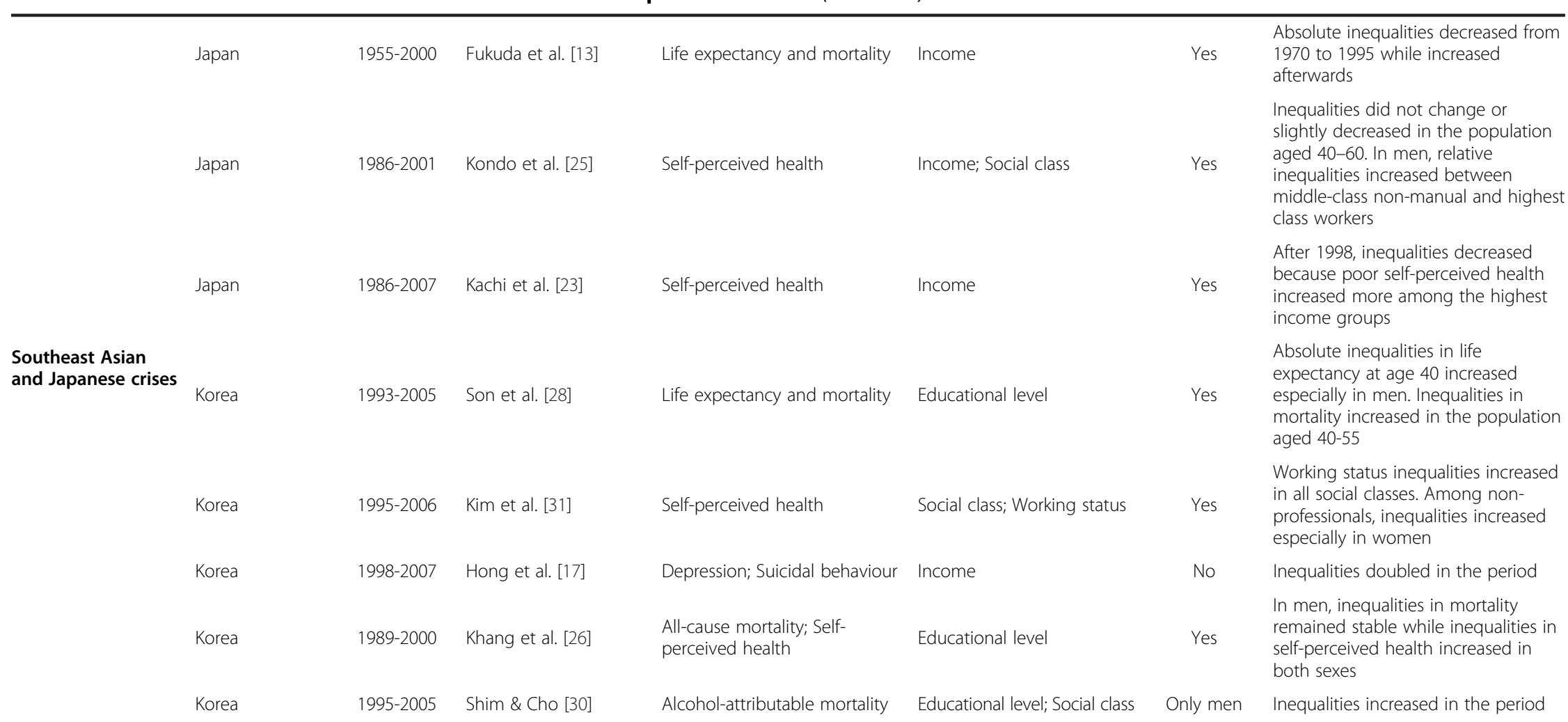


Secondly, we do not precisely know how deep the changes in the structural determinants of health must be in order to entail negative consequences in health for different social groups different social groups [35]. Nor is it clear in which health variables the effects of the crisis will be more rapidly noticeable [18]. It would seem logical that the effects on chronic health problems, on mortality from lung cancer -associated with an increase in smoking as a strategy for managing stress in crisis times-, or on disability shall be seen much later than other variables such as effects on self-perceived health or mental health [5].

Thirdly, the changes in the socioeconomic profile of the groups under comparison may also prevent from seeing an increase of inequalities in health. For example, in times of economic prosperity, the unemployed population is a small group of an especially disadvantaged socioeconomic profile, while in times of crisis, other less disadvantaged social groups can also become unemployed, which would weaken the usual relationship between unemployment and ill-health [36], at least among men [18]. This artificial phenomenon could consequently avoid that an increase in health inequalities among the employed and unemployed is seen during recessions $[12,18,19]$. However, this would not happen with other socioeconomic status variables such as educational level whose categories do not undergo rapid transformations by effect of the crisis.

Finally, the choice of measures to analyze the magnitude of inequalities and the changes may also influence the observed results. The exclusive use of effect measures in most of the studies -prevalence differences and ratios, or odds ratios- can omit a fundamental aspect: even if the strength of the relationship between socioeconomic status and health does not vary $[21,22]$ or even decreases [12], inequalities may instead be growing because the weight of the population facing the risk factors (i.e. unemployment, poverty, etc.) is in fact increasing. Therefore, measures of total population impact should be used complementarily, so that the changes in the distribution of the population along the socioeconomic variable can be considered, and the effect of the crisis on health equity better assessed. However, only some of the studies include these kind of measures [13,24-26,30,32].

\section{Conclusions}

This commentary has reviewed the studies that have examined so far the effects of the economic crises on social inequalities in health. Despite its wide methodological and approach variability, the negative impact of crises on health equity is shown, although not systematically. Additionally, some of the factors that can help shed some light on understanding their results have been described. However, the simultaneous occurrence of social phenomena in periods of pre-crisis and crisis both at the state and supranational level make any understanding of the health impacts very complex.

Similarly as it happened with the debate about the impact of the crisis on the population's health as a whole, it is likely that as the number of studies on the influence of the crisis on health equity increases, the scientific discourse will merge with the ideological one. The reason is that beyond what data indicate objectively, what is at stake is a much deeper debate about whether the neoliberal orientation of capitalism is exacerbating inequalities in health. In other words: which should be the best social and economical model for health equity?

To respond to this question, it will be convenient to incorporate new methodological approaches beyond hard quantification of impacts, which enables a better understanding of the negative consequences of current socioeconomic transformations for health and health equity. Moreover, we should not only be aware of the impacts of the current crisis, but also of those that will stem from the new social structure that is being progressively imposed by a minority [37] with the excuse of overcoming the crisis [38]. Therefore, today more than ever, epidemiology should enhance its social scope and work together with other disciplines to become more engaged in producing societies in which health equity is a central aim.

\section{Acknowledgments}

This work was partially supported by the University of the Basque Country, through its Grants for Research Projects (EHUA13/34).

\section{Author details}

'Department of Sociology 2, University of the Basque Country (UPV/EHU), Leioa, Spain. ${ }^{2}$ Local Health Authority, Cadiz, Spain.

Received: 11 May 2014 Accepted: 7 June 2014

Published: 25 July 2014

\section{References}

1. Eurostat: Euro area unemployment rate at $11.8 \%$. Eurostat News Release. 4/2013.

2. Catalano R, Goldman-Mellor S, Saxton K, Margerison-Zilko C, Subbaraman M, LeWinn K, Anderson E: The health effects of economic decline. Annu Rev Public Health 2011, 32:431-450.

3. Edwards R: Who is hurt by procyclical mortality? Soc Sci Med 2008, 67:2051-2058.

4. Catalano R, Bellows B: Commentary: if economic expansion threatens public health, should epidemiologists recommend recession? Int J Epidemiol 2005, 34:1212-1213.

5. Suhrcke $M$, Stuckler D: Will the recession be bad for our health? It depends. Soc Sci Med 2012, 74:647-653.

6. OECD: Education at al Glance 2013: OECD Indicators. OECD Publishing; 2013.

7. Laparra M, Pérez B, (coords): Crisis and Social Fracture in Europe. Causes and Effects in Spain. Social studies Collection no.35, Barcelona: "La Caixa" Welfare Projects; 2012.

8. Solar O, Irwin A: A Conceptual Framework for Action on the Social Determinants of Health. Social Determinants of Health Discussion Paper 2 (Policy and Practice). World Health Organization; 2010.

9. Stardfield B, Birn AE: Income redistribution is not enough: income inequality, social welfare programs, and achieving equity in health. J Epidemiol Community Health 2007, 61:1038-1041. 
10. Regidor E, Martínez D, Astasio P, Ortega P, Calle ME, Domínguez V: Trends of socioeconomic inequalities and socioeconomic inequalities in self-perceived health in Spain. Gac Sanit 2006, 20:178-183.

11. Gili M, Roca M, Basu S, McKee M, Stuckler D: The mental health risks of economic crisis in Spain: evidence from primary care centres, 2006-2010. Eur J Public Health 2013, 23:103-108.

12. Astell-Burt T, Feng X: Health and the 2008 economic recession: evidence from the United Kingdom. PLoS One 2013, 8:e56674.

13. Fukuda $Y$, Nakao $H$, Yahata $Y$, Imai $H$ : Are health inequalities increasing in Japan? The trends of 1955 to 2000. BioSci Trends 2007, 1:38-42.

14. Harhay MO, Bor J, Basu S, McKee M, Mindell JS, Shleton NJ, Stuckler D: Differential impact of the economic recession on alcohol use among white British adults, 2004-2010. Eur J Pub Health 2013, 16. doi:10.1093/ eurpub/ckt134.

15. Rajmil L, Medina-Bustos A, de Sanmamed MJ F, Mompart-Penina A: Impact of the economic crisis on children's health in Catalonia: a before-after approach. BMJ Open 2013, 3:1-9.

16. Plavinski SL, Pavinskaya SI, Klimov AN: Social factors and increase in mortality in Russia in the 1990s: prospective cohort study. BMJ 2003, 326:1240-1242.

17. Hong J, Knapp M, McGuire A: Income-related inequalities in the prevalence of depression and suicidal behaviour: a 10-year trend following economic crisis. World Psychiatry 2011, 10:40-44.

18. Lahelma E, Rahkonen $\mathrm{O}$, Huuhka M: Changes in the patterning of health? The case of Finland 1986-1994. Soc Sci Med 1997, 44:789-799.

19. Lahelma E, Kivela K, Roos E, Tuominen T, Dahl E, Diderichsen F, Elstad JI, Lissau I, Lundberg O, Rahkonen O, Rasmussen NK, Yngwe MA: Analysing changes of health inequalities in the Nordic welfare states. Soc Sci Med 2002, 55:609-625.

20. Valkonen T, Martikainen P, Jalovaara M, Koskinen S, Martelin T, Makela P: Changes in socioeconomic inequalities in mortality during an economic boom and recession among middle-aged men and women in Finland. Eur J Public Health 2000, 10:274-280

21. Lammintausta A, Immonen-Räihä R, Airaksinen JKE, Torppa J, Harald K, Ketonen M, Lehto S, Koukkunen H, Kesaniemi AY, Kärjä-Koskenkari P, Salomaa V: Socioeconomic inequalities in the morbidity and mortlity of acute coronay events in Finland: 1988-2002. Ann Epidemiol 2012, 22:87-93.

22. Lundberg $O$, Diderichsen $F$, Yngwe MA: Changing health inequalities in a changing society? Scand J Public Health 2001, 29:31-39.

23. Kachi Y, Inoue M, Nishikitani M, Tsurogano S, Yano E: Determinants of changes in income-related health inequalities among working-age adults in Japan, 1986-2007: Time-trend study. Soc Sci Med 2013, 81:94-101.

24. Bartoll $X$, Palència $L$, Malmusi $D$, Suhrcke $M$, Borrell $C$ : The evolution of mental health in Spain during the economic crisis. Eur J Public Health 2013. in press.

25. Kondo N, Subramanian SV, Kawachi I, Takeda Y, Yamagata Z: Economic recession and health inequalities in Japan: analysis with a national simple, 1986-2001. J Epidemiol Community Health 2008, 62:869-875.

26. Khang YH, Lynch JW, Yun S, Lee SI: Trends in socioeconomic health inequalities in Korea: use of mortality and morbidity measures. J Epidemiol Community Health 2004, 58:308-314.

27. Juárez S, Revuelta-Eugercios BA, Ramiro-Fariñas D, Viciana-Fernández F: Maternal education and perinatal outcomes among Spanish Women residing in Southern Spain (2001-2011). Matern Child Health J 2013. in press.

28. Murphy M, Bobak M, Nicholson A, Rose R, Marmot M: The widening gap in mortality by educational level in the Russian Federation, 1980-2001. Am J Public Health 2006, 96:1296-1299.

29. Son M, Cho Y, Oh J, Kawachi I, Yi J, Kwon S: Social inequalities in life expectancy and mortality during the transition period of economic crisis (1993-2010) in Korea. Int J Equity Health 2012, 11:71.

30. Shim $\mathrm{E}$, Cho $\mathrm{Y}$ : Widening social disparities in alcohol-attributable deaths among Korean men aged 40-59 years during the transitional period of the economic crisis (1995-2005). Int J Public Health 2013, 58:521-527.

31. H-Ho K, Khang YJ, Cho SI, Chun H, Muntaner C: Gender, professional and non-professional work, and the changing pattern of employment-related inequality in por self-rated health, 1995-2006 in South Korea. J Prev Med Public Health 2011, 44:22-31.
32. Katikireddi SV, Niedzwiedz CL, Popham F: Trends in population mental health before and after the 2008 recession: a repeat cross-sectional analysis of the 1991-2010 Health Surveys of England. BMJ Open 2012, $17: 2(5)$.

33. Lahelma $E$, Lundberg $O$ : Health inequalities in European welfare states. Eur J Pub Health 2009, 19:445-446.

34. Curran C, Knapp M, McDaid D: Mental health and employment: an overview of patterns and policies across Western Europe. $J$ Ment Health 2007, 16:195-209.

35. van de Berg GJ, Lindeboom M, Lopez M: Inequality in individual mortality and economic conditions earlier in life. Soc Sci Med 2009, 69:1360-1367.

36. Martikainen PT, Valkonen T: Excess mortality of unemployed men and women during a period of rapidly increasing unemployment. Lancet 1996, 348:909-912

37. Klein N: The Shock Doctrine: The Rise of Disaster Capitalism. Ontario: Knopf Canada; 2007.

38. Bauman Z: Does the richness of the few benefit us all? Soc Eur J.28/01/ 2013. [http://www.social-europe.eu/2013/01/does-the-richness-of-the-fewbenefit-us-all/]

doi:10.1186/1475-9276-13-52

Cite this article as: Bacigalupe and Escolar-Pujolar: The impact of economic crises on social inequalities in health: what do we know so far? International Journal for Equity in Health 2014 13:52.

\section{Submit your next manuscript to BioMed Central and take full advantage of:}

- Convenient online submission

- Thorough peer review

- No space constraints or color figure charges

- Immediate publication on acceptance

- Inclusion in PubMed, CAS, Scopus and Google Scholar

- Research which is freely available for redistribution 